\title{
Determinants for Consumer Attitude towards Technology Enabled Grocery Procurement
}

\author{
Deepshikha Aggarwal
}

\begin{abstract}
Online grocery shopping is trending worldwide as one of the most expedient e-commerce practice. Many people have started purchasing their grocery online and this has given the opportunity to the researchers to identify and analyse the factors that influence the consumers for making online purchases. We have observed that until around 5 years back, the daily grocery requirements of the Indian consumers were fulfilled by the local kirana store and to some extent by the emerging hypermarkets/supermarket. But, with the popularity of internet and penetration of smartphones into the daily lives of the people, several online grocery stores have been able to penetrate the Indian markets. The busy lives of people especially the urban working population, makes the online grocery shopping a popular choice. With traditional households still being widely spread in the Indian society, the online companies need to have a resounding approach to influence the buying habits and shopping patterns of the consumers. The aim of this study is to understand the attitude of Indian consumers towards online grocery shopping and determine the factors that influence the consumer decision making to shop groceries online. The primary data is collected using a well-thought-out questionnaire in the form of an online survey. Data collected was analysed to determine the consumer attitude towards online grocery shopping. The findings of the study show that the consumers are influenced by various factors like time saving and convenience provided by the online grocery shopping platforms. They are also influenced by the quality of products and the return policy as well as the level of comfort while using the online shopping website/app. We have also been able to understand the reasons that prevent people from online shopping. Some people find themselves lacking the technical skills to shop online, but most people who do not shop online like going to the market personally. In case of online shopping, an area of concern for most shoppers is trust on the online applications. People are concerned about the privacy of their personal information while shopping online and needs thoughtfulness of the retailers to encourage more consumers to opt for online shopping platforms. In this paper we have comprehensively explored different areas associated with online grocery shopping and this study can be advantageous for the online grocery retailers to articulate effective policies to gain customer confidence towards online grocery shopping.
\end{abstract}

Keywords: Online Grocery Shopping, Data Analytics, Consumer behaviour, ecommerce, marketing strategy

Revised Manuscript Received on February 05, 2020.

* Correspondence Author

Deepshikha Aggarwal, Professor, Department of Information Technology Jagan Institute of Management Studies, Delhi, India deepshikha.aggarwal@jimsindia.org

(C) The Authors. Published by Blue Eyes Intelligence Engineering and Sciences Publication (BEIESP). This is an open access article under the CC BY-NC-ND license (http://creativecommons.org/licenses/by-nc-nd/4.0/)

\section{INTRODUCTION}

The online grocery shopping is evolving rapidly in the ecommerce industry as more and more people have started to buy food and other household products online. Online grocery shopping is different from other categories of ecommerce such as fashion and travel as it majorly involves food items and therefore has to keep focusing on quality, freshness and durability of products more than anything else. Another important aspect is that the shoppers for online grocery are using these products on a daily basis so the reputation of the seller is depending on the offered services. The aim of this paper is to understand the behavior and expectations of online grocery shoppers in India. The paper focuses on the choice of products and service expectations of the consumers. The research will help in determining the factors that influence the decision making of the consumer when it comes to online grocery shopping. The analysis was done on a sample of over 100 respondents by means of questionnaire circulated through email. The sample consisted of both the shoppers who purchased grocery online and the ones who did not purchase grocery online. The reasons for not shopping grocery online have also been analyzed.

Most of the people today find Internet as an interesting way to share information, communicate with friends and family, read news, look for job or travel options, buying and selling goods and services and the list goes on. In spite of all these uses of the internet and more, online grocery shopping has still not become a very popular option. There are too many personal factors that dominate the consumer's decision for online grocery shopping. People are generally very particular about the choice of products, brands and even stores when it comes to grocery shopping. [1].

\section{RELATED WORK}

Electronic commerce provides the consumers various options to select the products and services that they wish to purchase. These increased choices have a significant impact on the consumer decision making in digital marketplace. This intensifies the challenges for the ecommerce retailers to predict the buying pattern of their customers. The research findings [2] show that with the growth of online marketplaces, the consumers are much more aware about the available products and therefore the sellers have to find suitable methods to influence and retain their consumers.

Online grocery industry is comparatively a new entrant in the ecommerce sector and has recently started gaining popularity among the masses especially in India. The growing consumer interest in buying grocery online has made this industry the current most evolving e-commerce category. 


\section{Determinants for Consumer Attitude towards Technology Enabled Grocery Procurement}

The ecommerce retailers have realized that they need to focus on the factors influencing the decision making of the consumers in order to achieve their business growth. Online Grocery Shopping is different from general ecommerce as it involves the food items and the consumers are more concerned about the quality, freshness and durability of products. Also the consumers look for merchant promotional offers and services and delivery conditions of the online purchase process.

The research results [3] show that the delivery time and delivery charge have a high impact, while the impact of the minimum order value on the consumer's intention to shop grocery online is not so pivotal [4].

The current trends in the growth of online shopping clearly indicate that the e-retailers and manufacturers need to focus on the consumers' behavior while shopping online and develop their marketing strategies accordingly. Online shopping environments offer certain facilities and advantages that influence the consumer's decision-making process. The most frequently cited characteristics of online grocery shopping are time-saving [5] and saving of effort during the purchase process [6].

\section{RESEARCH OBJECTIVES}

Electronic commerce is an interesting area of research as we see that more and more people around us are talking about online shopping and their various experiences and views. These observations were a powerful motivator for the current research. The augmentation of the Internet has thrusted the consumer retail industry into an electronic age. The growth of ecommerce is changing every facet of our daily lives with respect to our shopping habits and actions. The changes are observed right from how consumers gather information and learn about the products and services, to how they shop and buy products and services [7].

The process of online grocery shopping is primarily divided into following stages:

- Recognising the need to purchase a product

- Identifying the different purchase options

- Search the product

- Evaluation of alternatives in terms of price and variety

- Purchase

- Customer service and returns

The consumers are affected by various factors while making a decision to shop online. An important observation is that the consumers are influenced by their individual characteristics, social stimuluses and situational and economic aspects [8]. As the shopping experience is online, the web influencers such as the quality of website, the interface design customer convenience and satisfaction while using the website act as the external factors influencing the online consumer decision making process [9].

The online grocery stores need to focus on each of these stages in order to attract and retain the consumers. On the basis of the stages of the online grocery selling process, we have identified the following research objectives.
- Study the impact of different features of the online grocery shopping apps/websites that impact the shopping decision of consumers.

- Identifying the grocery items that are bought online more and the areas of concern for the consumers while shopping online.

- Analysing the reasons that have a positive impact on consumers while shopping of grocery online

- Identifying the reasons that prevent consumers from shopping the grocery online.

\section{RESEARCH METHODOLOGY}

The study is conducted on primary data collected by us. First we conducted in depth interviews of 20 to 25 people to have an overall impression of the views of Indian consumers on shopping the grocery online. Though some people still want to stay with the traditional "kiranawala" approach but many people have explored the option of grocery shopping online. On the basis of the information collected from these interviews, a questionnaire was prepared in accordance with the research objectives. The questionnaire was circulated by means of email and WhatsApp to around 150 people. Total number of responses received was 135 out of which 125 responses were complete and have been used in the study to derive results. Out of the 125 respondents, 80 have shopped for grocery online and 45 have never shopped for grocery online.

Table1: Data demographics

\begin{tabular}{|l|l|l|}
\hline \multirow{2}{*}{ Gender } & Male & $57.7 \%$ \\
\cline { 2 - 3 } Age Group & Female & $42.3 \%$ \\
\hline & less than 25 years & $17.3 \%$ \\
\cline { 2 - 3 } & $25-35$ years & $32.7 \%$ \\
\cline { 2 - 3 } & $35-45$ years & $28.8 \%$ \\
\cline { 2 - 3 } & $45-50$ years & $13.5 \%$ \\
\cline { 2 - 3 } & Above 50 years & $7.7 \%$ \\
\hline \multirow{4}{*}{ Occupation } & Professional/ Work \\
full time & $63.3 \%$ \\
\cline { 2 - 3 } & Work part time \\
\cline { 2 - 3 } & Stay at home \\
\cline { 2 - 2 } & Student \\
\hline \multirow{3}{*}{$\begin{array}{l}\text { Have you purched } \\
\text { grocery online? }\end{array}$} & YES & $15.4 \%$ \\
\cline { 2 - 2 } & NO \\
\hline
\end{tabular}

Table 2: Websites/ Apps used for online grocery shopping

\begin{tabular}{|l|l|}
\hline Name of the website & Percentage of users \\
\hline BigBasket & $62.5 \%$ \\
\hline Grofers & $60 \%$ \\
\hline Amazon & $62 \%$ \\
\hline Godrej Nature's Basket & $2.5 \%$ \\
\hline Others (MilkBasket, Snapdeal, ebay) & $25 \%$ \\
\hline
\end{tabular}

\subsection{Items bought Online}

As a part of this research, we explored the different online grocery shopping websites and identified the product categories sold. During the interviews with respondents, we identified the most common items that are purchased through online grocery websites and the questions related to these products were prepared and incorporated into the questionnaire. 
The responses were analysed on the basis of the frequency of purchase of the items. The observations are shown in Table 3.

Table 3: Items bought online

\begin{tabular}{|c|c|c|c|}
\hline Product & $\begin{array}{c}\text { Bought } \\
\text { Once }\end{array}$ & $\begin{array}{c}\text { Bought more } \\
\text { than once }\end{array}$ & Not bought \\
\hline $\begin{array}{c}\text { Fruits \& } \\
\text { Vegetables }\end{array}$ & 8 & 40 & 32 \\
\hline $\begin{array}{c}\text { Food grains \& } \\
\text { Staples }\end{array}$ & 14 & 38 & 28 \\
\hline $\begin{array}{c}\text { Cooking oils \& } \\
\text { spices }\end{array}$ & 16 & 36 & 28 \\
\hline $\begin{array}{c}\text { Bakery \& } \\
\text { sweets }\end{array}$ & 11 & 39 & 30 \\
\hline Dairy products & 10 & 34 & 36 \\
\hline Beverages & 12 & 52 & 16 \\
\hline $\begin{array}{c}\text { Snacks \& } \\
\text { Breakfast } \\
\text { cereals }\end{array}$ & 16 & 50 & 14 \\
\hline $\begin{array}{l}\text { Cleaning \& } \\
\text { Household }\end{array}$ & 8 & 54 & 18 \\
\hline Eggs/ Meats & 14 & 20 & 46 \\
\hline Gourmet foods & 20 & 18 & 42 \\
\hline
\end{tabular}

\begin{tabular}{|c|c|c|c|}
\hline $\begin{array}{c}\text { Ready to cook } \\
\text { foods }\end{array}$ & 10 & 54 & 16 \\
\hline Personal care & 15 & 33 & 32 \\
\hline $\begin{array}{c}\text { Frozen } \\
\text { products }\end{array}$ & 12 & 24 & 44 \\
\hline $\begin{array}{c}\text { Baby food \& } \\
\text { baby products }\end{array}$ & 8 & 40 & 32 \\
\hline
\end{tabular}

It indicates that the maximum number of consumers have never bought eggs/ meat and frozen foods online which indicates that they may be concerned about the perishable goods getting spoilt in transportation.

The most popular products bought online frequently by the consumers are ready to cook foods, Cleaning \& Household products and beverages. Also the item purchased by most of the respondents is Snacks \& Breakfast cereals.

\subsection{Features of online grocery shopping}

There are various feature related to the shopping websites, products and services provided by the online grocery retailers that influence the consumers while decision making for online grocery shopping. The interviews conducted with the respondents enabled us to categorise these features. The following features of the grocery shopping apps/websites have been identified and the impact they make on the consumers' buying decision have been analyzed.

Table 4: Features impacting consumer decision

\begin{tabular}{|l|l|l|}
\hline \multirow{5}{*}{ Website/App Features } & Feature & $\begin{array}{l}\text { Positive impact on } \\
\text { shopping }\end{array}$ \\
\hline & $\begin{array}{l}\text { Look and Design of the website/ } \\
\text { app }\end{array}$ & $39.50 \%$ \\
\cline { 2 - 3 } & Speed of Loading the Pages & $78.60 \%$ \\
\cline { 2 - 3 } & $\begin{array}{l}\text { Ease of Navigation through the } \\
\text { website/ app }\end{array}$ & $88.10 \%$ \\
\cline { 2 - 3 } & Product Details and photos & $90.50 \%$ \\
\hline & Checkout and payment Process & $85.70 \%$ \\
\hline \multirow{5}{*}{ Product Features } & Attractive Price and Discounts & $90.70 \%$ \\
\cline { 2 - 3 } & Quality of Products & $97.60 \%$ \\
\cline { 2 - 3 } & Variety of Products & $93 \%$ \\
\hline & $\begin{array}{l}\text { Feedback and Reviews of other } \\
\text { shoppers }\end{array}$ & $65.10 \%$ \\
\cline { 2 - 3 } & Delivery Time & $88.10 \%$ \\
\cline { 2 - 3 } & Packaging Quality & $78.60 \%$ \\
\cline { 2 - 3 } & Returns and exchange policy & $90.70 \%$ \\
\hline
\end{tabular}

It is indicated from Table 2 that BigBasket, Amazon and Grofers are most popular websites for online grocery shopping. Table 4 indicates that among the website related features, product details and photos and ease of Navigation through the website/ app are the most important features. For the product related features the most important is Quality of Products and the most important service feature is returns and exchange policy.

Apart from the features mentioned in Table 4, we have identified a number of reasons that motivate the people to shop for grocery online. These reasons for your shopping of grocery online have been rated on a scale of 1 to 3 where 1 indicates a low impact and 3 indicate a high impact.

Table 5: Reasons for shopping online 


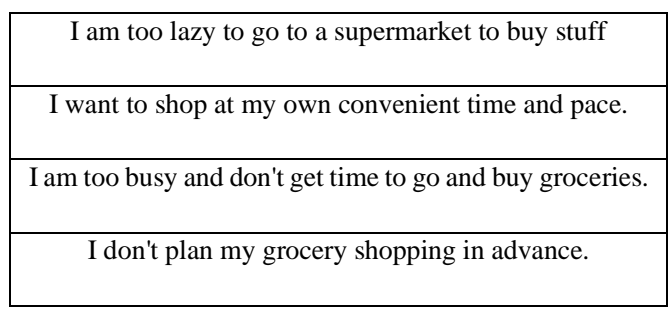

Observations from Table 5 have been shown in Fig 1. It is observed that the reason for online shopping that has the highest impact on the consumers is that it saves their time. Other reasons that encourage people to shop for grocery online are that it saves the consumers' money as prices are low \& promotional schemes are offered. People want to help their spouse/ parents by sharing responsibility of house work. They want to shop at their own convenient time and pace and many people don't plan their grocery shopping in advance. These factors motivate the shoppers to choose online grocery shopping over the traditional shopping methods.

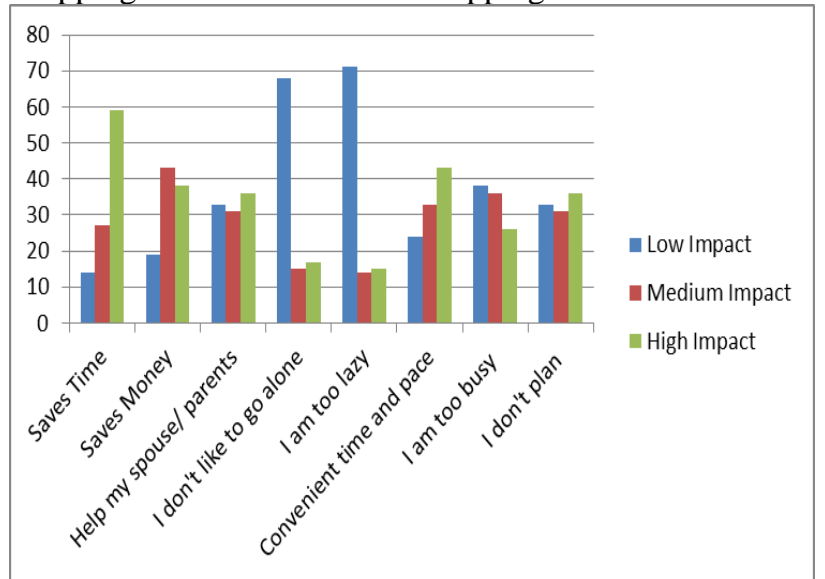

Fig 1: Impact of different reasons on consumers for online shopping

\subsection{Trust in online shopping}

For the people who are shopping online, trust remains an area of concern. Few questions were asked to the respondents about the security of their personal information while they shop online and the results indicate that it remains an issue of concern for the consumers.

Respondents were asked whether they pay for their shopping through online payment methods and the observation is shown in Fig 2. They were also asked whether they are concerned about the privacy of their personal details while shopping for grocery online and the observation is shown in Fig 3

Though more than half of the respondents pay for their shopping online, 64.3\% respondents are concerned about privacy of your personal details while shopping for grocery online.

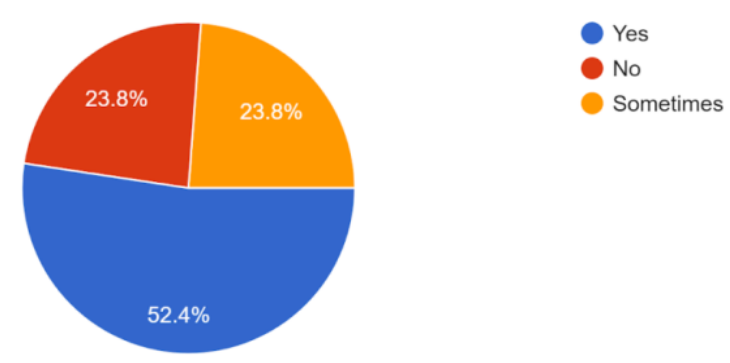

Fig 2: Online payments

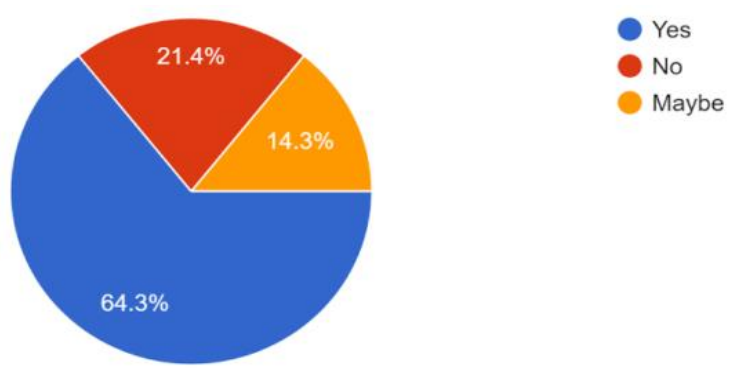

Fig 3: Concern over Privacy

\subsection{Reasons for not shopping for grocery online}

Online shopping is perceived to have certain disadvantages as compared to the brick and mortar stores, such as shipping and handling charges, return and exchange policies, providing a social or family environment, interaction with salespeople, after sales service, and ambiguity to select the desired products [10]. Though recompenses provided by the online stores in providing a wider variety of brands and products, ease of shopping, etc. as mentioned in Table 4 overcome the disadvantages to a large extent. The results of previous research [11] indicate that there are several situational factors that can influence the consumers' shopping preference to shop online or not. The consumers' intention to buy grocery online can be affected by factors such as delivery charges or travel time to the grocery store. Different people would be influenced by different factors and the factors that influence them most would lead to the decision whether they will shop online or not.

Table 1 indicates that $64 \%$ of the respondents shop for grocery online, yet a considerable population is still comfortable shopping through the traditional brick and mortar stores.

In this paper we have identified several consumer centric factors that prevent the consumers to try online grocery shopping. These factors have been summarized as follows: 


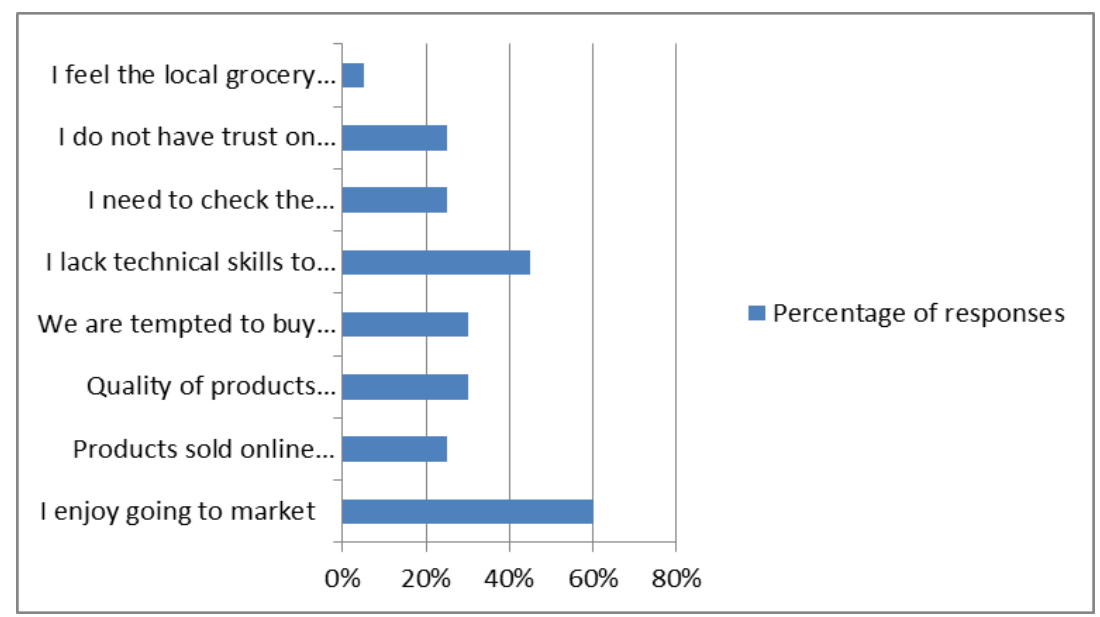

Fig 4: Reasons for not shopping grocery online

This part of our research is focusing on the personal opinion of the respondents about online shopping and we have analyses the reasons that make them decide to shop in traditional manner. The main reason that people give to not shop online is that they enjoy going to the market. Another influencing factor here is lack of technical skills because some people who are not confident to use electronic devices, do not get involved in online shopping.

\section{RESULTS}

The Research Objective 1 is to study the impact of different features of the online grocery shopping apps/websites that impact the shopping decision of consumers. The results are shown in Table 6.

Table 6: Results for impact of features of online grocery apps/ websites

\begin{tabular}{|c|c|}
\hline Feature & $\begin{array}{c}\text { Positive } \\
\text { impact on } \\
\text { shopping }\end{array}$ \\
\hline Quality of Products & $97.60 \%$ \\
\hline Variety of Products & $93 \%$ \\
\hline Attractive Price and Discounts & $90.70 \%$ \\
\hline Returns and exchange policy & $90.70 \%$ \\
\hline Product Details and photos & $90.50 \%$ \\
\hline Ease of Navigation through the website/ app & $88.10 \%$ \\
\hline Delivery Time & $88.10 \%$ \\
\hline Checkout and payment Process & $85.70 \%$ \\
\hline Speed of Loading the Pages & $78.60 \%$ \\
\hline Packaging Quality & $78.60 \%$ \\
\hline Look and Design of the website/ app & $39.50 \%$ \\
\hline
\end{tabular}

The results indicate that Quality of products is the most important feature for online grocery procurement followed by variety of products, price \& discounts and returns \& exchange policy. The least important feature for the users is look and design of the website.

The Research objective 2 is identifying the grocery items that are bought online more and the areas of concern for the consumers while shopping online. The results are shown in Table 7.

Table 7: Results for products bought

\begin{tabular}{|c|c|}
\hline Product & Frequency of purchase \\
\hline Cleaning \& Household & 54 \\
\hline Ready to cook foods & 54 \\
\hline Beverages & 52 \\
\hline Snacks \& Breakfast cereals & 50 \\
\hline Fruits \& Vegetables & 40 \\
\hline Baby food \& baby products & 40 \\
\hline Bakery \& sweets & 39 \\
\hline Food grains \& Staples & 38 \\
\hline Cooking oils \& spices & 36 \\
\hline Dairy products & 34 \\
\hline Personal care & 33 \\
\hline Frozen products & 24 \\
\hline Eggs/ Meats & 20 \\
\hline Gourmet foods & 18 \\
\hline
\end{tabular}

The results indicate that Cleaning \& Household, Ready to cook foods and beverages are the most frequently bought commodities through online medium.

Research objective 3 is analysing the reasons that have a positive impact on consumers while shopping of grocery online. The results are shown in Table 8.

Table 8: Results for reasons for shopping online

\begin{tabular}{|l|l|}
\hline \multicolumn{1}{|c|}{ Reason } & \multicolumn{1}{|c|}{ Impact } \\
\hline $\begin{array}{l}\text { It saves my time as I don't have } \\
\text { to travel to the store. }\end{array}$ & High \\
\hline $\begin{array}{l}\text { I don't plan my grocery shopping } \\
\text { in advance. }\end{array}$ & High \\
\hline $\begin{array}{l}\text { I want to help my spouse/ } \\
\text { parents by sharing responsibility } \\
\text { of house work. }\end{array}$ & High \\
\hline $\begin{array}{l}\text { I want to shop at my own } \\
\text { convenient time and pace. }\end{array}$ & High \\
\hline $\begin{array}{l}\text { It saves money as prices are low } \\
\text { \& promotional schemes are } \\
\text { offered. }\end{array}$ & Medium \\
\hline $\begin{array}{l}\text { I don't have company to go for } \\
\text { grocery shopping and I don't like } \\
\text { to go alone. }\end{array}$ & Low \\
\hline
\end{tabular}

Published By:

Blue Eyes Intelligence Engineering 


\section{Determinants for Consumer Attitude towards Technology Enabled Grocery Procurement}

\begin{tabular}{|l|l|}
\hline $\begin{array}{l}\text { I am too lazy to go to a } \\
\text { supermarket to buy stuff }\end{array}$ & Low \\
\hline $\begin{array}{l}\text { I am too busy and don't get time } \\
\text { to go and buy groceries. }\end{array}$ & Low \\
\hline
\end{tabular}

The results indicate that time saving, unplanned shopping, helping the family and convenience are the high impact factors for online grocery procurement.

The Research Objective 4 is identifying the reasons that prevent consumers from shopping the grocery online. The results are shown in Table 9.

Table 9: Results for reasons for not shopping online

\begin{tabular}{|l|l|}
\hline Reason for not shopping online & $\begin{array}{l}\text { Percentage } \\
\text { responses }\end{array}$ \\
\hline I enjoy going to market & 60 \\
\hline $\begin{array}{l}\text { I need to check the products myself } \\
\text { before purchase. }\end{array}$ & 45 \\
\hline $\begin{array}{l}\text { Quality of products sold online is } \\
\text { not good }\end{array}$ & 30 \\
\hline $\begin{array}{l}\text { We are tempted to buy things we do } \\
\text { not need }\end{array}$ & 30 \\
\hline $\begin{array}{l}\text { Products sold online are more } \\
\text { expensive }\end{array}$ & 25 \\
\hline $\begin{array}{l}\text { I do not have trust on online } \\
\text { retailers. }\end{array}$ & 25 \\
\hline $\begin{array}{l}\text { I feel the local grocery shop owners } \\
\text { are suffering due to online retailers }\end{array}$ & 25 \\
\hline Ability to Bargain & 5 \\
\hline I lack technical skills to shop online & 0 \\
\hline
\end{tabular}

The results indicate that enjoyment associated with going to market is the most important factor that discourages people to use technology for procurement of grocery.

\section{DISCUSSIONS \& CONCLUSION}

This research has been conducted to understand the attitude of Indian consumers for the adoption of online grocery shopping. The respondents were chosen from different locations across India and were from different cultural and social backgrounds. The study has been divided into two parts. One part focuses on the people who shop for grocery online and the second part focused on the people who do not shop for the grocery online. The people who shop for grocery online are influenced by different features of online shopping websites and also they have various reasons that encourage them to shop for groceries online.

The most important feature for the consumers is the quality of products. Other important features are variety of products, returns and exchange policy, attractive prices and discounts and product details and photos. The main factor that encourages people to shop online is that it saves their time. Saving money through discounts and promotions is also having an impact on the shoppers. The shopping frequency depends on the type of products. Some products are bought more frequently and the overall purchase of perishable products is low. We have been also able to identify the main reasons for shoppers not buying grocery online. Most of the people who do not shop online, enjoy going to the market. Technical skills of the shoppers also play a role in their decision to shop online.

Through this study, we have been able to fulfil all our research objectives and have led to the conclusion that the Indian consumers are developing a positive attitude towards adoption of online grocery shopping. There are certain areas that need the attention of the ecommerce vendors in order to promote the online grocery shopping. The observations shown in this paper can be used as a tool for development and improvement of the online grocery business. One important area where work needs to be done is the privacy concern of the consumers. If the consumers are given an assurance that their personal information is safe, they will be more willing to start purchasing online. In future, we plan to take up this research on a larger population and study the various other factors that play a role in online grocery shopping.

The general views of the respondents about online grocery shopping have been shown with the help of a word cloud in Fig 5.

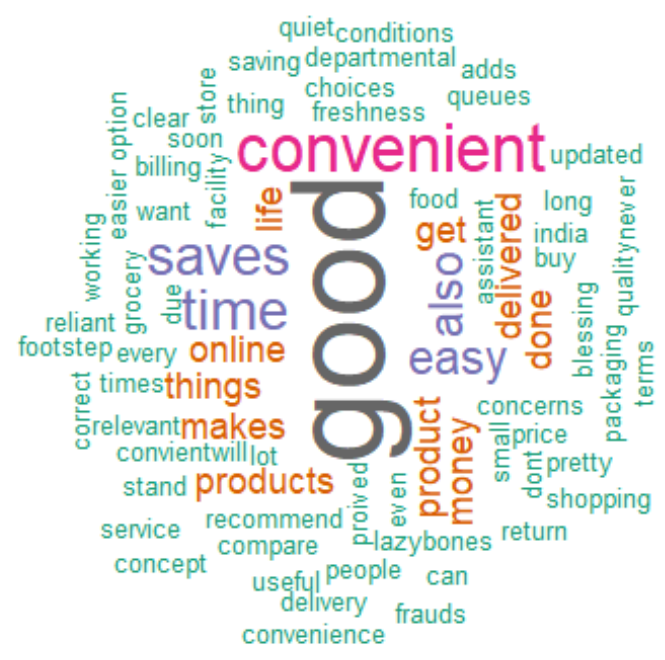




\section{REFERENCES}

1. G. P. LANTOS, Consumer Behavior in Action: Real life Applications for Marketing Managers., New York: Routledge, 2015.

2. S. K. M. S. L. N. P. R. Y. K. D. Anil Kumar, "Predicting changing pattern: building model for consumer decision making in digital market," Journal of Enterprise Information Management, 2018.

3. R. Bauerová, "Consumers' Decision Making in Online Grocery Shopping: The Impact of Services Offered and Delivery Conditions," Acta Universitatis Agriculturae et Silviculturae Mendelianae Brunensis., 2018.

4. Y. a. O. H. HUANG, " Why consumers hesitate to shop online: An experimental choice analysis of grocery shopping and the role of delivery fees.," International Journal of Retail and Distribution Management, 2006.

5. Z. A. M. N. J. D. R. Kennedy, "How do shoppers behave online? An observational study of online grocery shopping," Jounal of Consumer Behaviour, 2015.

6. R. a. R. P. SREYA, "Effect of shopping orientations on attitude towards online shopping - a multiple regression approach," Management Insight, 2017.

7. J. \&. L. S. Kim, "Effects of reputation and website quality on online consumers' emotion, perceived risk and purchase intention: Based on the stimulus-organism-response model," Journal of Research in Interactive Marketing, 2013.

8. C. \&. D. R. F. \&. H. P. \&. S. J. \&. R. R. Hand, "Online grocery shopping: The influence of situational factors.," European Journal of Marketing., 2009.

9. W. K. B. C. a. L. D. J. DARLEY, "Toward an integrated framework for online consumer behavior and decision making process: A review," Psychology \& Marketing, 2010.

10. A. l. o. o. p. J. D.-Y. Chiangb, "Bricks or Clicks? Consumer Attitudes toward Traditional Stores and Online Stores," Global Economics and Management Review, 2013.

11. H. O. Yan Huang, "Why consumers hesitate to shop online: An experimental choice analysis of grocery shopping and the role of delivery fees," International Journal of Retail \& Distribution Management, 2006.

\section{AUTHOR'S PROFILE}

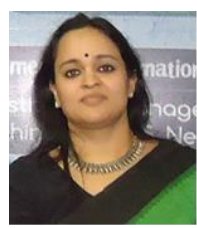

Dr. Deepshikha Aggarwal, is working as a Professor in Department of Information Technolog, Jagan Institute of Management Studies, Delhi, India. A highly accomplished faculty and researcher with extensive experience of over 18 years in academia. She has done B.E., M. Tech and PhD in Computer Science. She has written several research papers for various National and International journals and presented papers at different seminars and conferences. Her research interests include Social Network Analysis, Data quality, Computer networks, cyber security, E-learning and Data Science. 